DARIUSZ ROLNIK

Uniwersytet Śląski w Katowicach

(iD) ORCID ID: 0000-0002-7649-3142
WŁADZA I POLITYKA

W CZASACH NOWOŻYTNYCH

DYPLOMACJA I SPRAWY WEWNĘTRZNE

\title{
Sztuka „dyplomacji” i jej znaczenie w wewnętrznym życiu publicznym czasów stanisławowskich - o klientelizmie i nieprzypadkowych karierach myśli kilka
}

The art of "diplomacy" and its significance in the internal public life of the period of King Stanislaw's reign - some remarks about the clientelism and careers which were not accidental

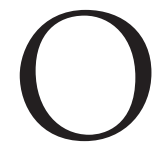

klientelizmie w dawnej Rzeczypospolitej napisano już sporo, w większości trafnie oceniając negatywnie taki system sprawowania władzy czy prowadzenia polityki ${ }^{1}$. Problem polega jednak na odpowiednim ujęciu zależności w relacjach między patronem-opiekunem a tym, kto korzysta z takiego stosunku. „Tłuszcza szlachecka” zwożona na sejmik to nie to samo, co piastujący nawet niski urząd w hierarchii ziemskiej obywatele, którzy nominację zawdzięczają wsparciu

* Artykul powstał w wyniku prac nad projektem NCN 2014/15/B/HS3/02277, pt. Adam Chmara (1720-1805) - ostatni wojewoda miński w świecie polityki czasów stanistawowskich i jego archiwum.

${ }^{1}$ O kwestii definicji klientelizmu i pojęć klient-obywatel pisze A. Mączak, Rzeczypospolita, [w:] Od plemion do Rzeczypospolitej. Naród, państwo, terytorium w dziejach Polski, red. A. Mączak, Warszawa 1999, s. 120; idem, Klientela. Nieformalny system wtadzy w Polsce i Europie XVI-XVIII w., Warszawa 1994, s. 5-34, 161-172, 211-266, 275-297; idem, Nierówna przyjaźń. Uktady klientalne w perspektywie historycznej, Wrocław 2003, s. 159-207; U. Augustyniak, Dwór i klientela Krzysztofa Radziwitta (1585-1640). Mechanizmy patronatu, Warszawa 2001, passim; eadem, Granice wolności obywatela Rzeczypospolitej $w$ XVI-XVII w. Jednostka wobec wtadzy, prawa i spoteczeństwa, [w:] Wolność i jej granice. Polskie dylematy, red. J. Kłoczkowski, Kraków 2007, s. 13-36; S. Grodziski, Obywatelstwo w szlacheckiej Rzeczypospolitej, Kraków 1963, s. 7-39, 163-196; W. Tygielski, Klientela: więzi spoteczne - grupa nacisku, [w:] Wtadza i spoteczeństwo. Prace ofiarowane A. Mączakowi, red. Z. Stefaniak, Warszawa 1989, s. 261-282; J. Wojtasik, Drobna szlachta podlaska w wojsku Rzeczypospolitej i powstaniach narodowych (XVII-XIX w.), [w:] Drobna szlachta podlaska w XVI-XIX wieku, red. S.K. Kuczyński, Białystok 1991, s. 29-36; W. Majewski, Granice uzależnienia szlachty od magnaterii w XVII-XVIII wieku, [w:] ibidem, s. 113-123; J. Tazbir, Świat panów Pasków. Eseje i studia, Łódź 1986, s. 5 i n. 
możnego pana. Ta druga grupa, w moim odczuciu, przynajmniej w czasach stanisławowskich to w sporej części nie klienci, a współpracownicy możnych, którzy nader często zmieniali dobroczyńców czy „pracodawców”. To grupa zawodowych polityków-urzędników, mająca już podstawy ekonomiczne do podjęcia się takiej roli i odpowiednie doświadczenie w życiu publicznym, pozwalające na kreowanie swojej małej polityki, niekoniecznie zależnej od wcześniejszego protektora. Wiążą się z tym takie zagadnienia, jak autorytet w mniejszych społecznościach, np. powiecie czy województwie, a również kwestie ideologiczne, które w miarę upływu czasu stawały się coraz istotniejsze, ważniejsze niż niekiedy tylko na chwilę uzyskiwane korzyści. Nie ulega wątpliwości, że oceny polityków - z czym łączyła się ich „cena” na „rynku” działań publicznych - były wynikiem ich skuteczności w działaniach na sejmikach, ale również w przestrzeni ogólnokrajowej na sejmach czy trybunałach oraz w pełnieniu funkcji w różnych komisjach bądź Radzie Nieustającej. Oczywiście różne aspekty decydowały o powodzeniu w działalności publicznej. Wydaje się, że jednym z najistotniejszych była swoista sztuka „dyplomacji”, rozumiana tutaj jako umiejętność zachowania się, przyjęcia odpowiedniej postawy w toczonych bataliach politycznych na wszystkich wskazanych wyżej szczeblach, która zapewni osiągnięcie zamierzonego celu. Tak ujęte zagadnienie nie podlegało dotąd badaniu. W artykule tym, na przykładzie analizy kliku postaci szczycących się osiągnięciem godności senatorskiej, ukazano wagę „dyplomacji” w drodze po zaszczyty. Pojęcie „dyplomacji” w niniejszym tekście będzie rozumiane zgodnie z definicją Cycerona, który głosił: „Istnieją dwa sposoby rozstrzygania sporów: jeden przy pomocy argumentów, drugi przy użyciu siły; a ponieważ pierwszy z nich jest właściwy człowiekowi, a drugi dzikim zwierzętom, należy uciec się do drugiego sposobu tylko wówczas, gdy nie możemy użyć pierwszego" ${ }^{2}$. De facto znaczy to tyle, co przekonanie swoim słowem, zachowaniem czy postawą do swoich racji, w omawianych tu przypadkach na płaszczyźnie relacji międzyludzkich i w działaniach publicznych i politycznych. Pojęcie dyplomacji jako służby państwu nie jest tu brane pod uwagę.

Analizie oceniającej wagę zdolności dyplomatycznych w drodze do kariery politycznej poddano awanse trzech senatorów czasów stanisławowskich, którzy wówczas jako pierwsi w historii swych rodów osiągnęli godność senatora. Są to: Adam Chmara, ostatni wojewoda miński, Gedeon Jeleński, kasztelan nowogródzki i Leonard Marcin Świeykowski, ostatni wojewoda podolski. Rodziny Chmarów i Świeykowskich jeszcze

2 Cyt. za: J. Sutor, Pokojowe zatatwianie sporów międzynarodowych, Wrocław 1979, s. 15.

3 Tu pewna nieścisłość, ale także świadomy zabieg poczyniony dla jasności przekazu. Pierwszym senatorem w rodzinie Jeleńskich był Rafał, kasztelan nowogródzki, wszak zyskał ją dzięki aktywności i „dyplomacji” Gedeona, który po jego śmierci ją właściwie „odziedziczył”. D. Rolnik, Województwo mińskie i Jeleńscy w życiu publicznym Rzeczypospolitej $w$ latach 1764-1795 w świetle ich korespondencji, Katowice 2018, s. 174-188. 
w początkach XVIII w. zaliczały się do drobnej szlachty, nieco wyżej sytuować można Jeleńskich (była to średnia szlachta) ${ }^{4}$.

Omawiane kariery pod pewnymi względami były bardzo podobne. Właściwie wszyscy karierę rozpoczynali pod opieką możnych rodów. Może najmniej była ona potrzebna Jeleńskiemu, ale z pomocy Sapiehów i Radziwiłłów korzystał chętnie ${ }^{5}$. Wszyscy opiekę możnych wykorzystali dla własnych celów bardzo dobrze i skutecznie. Chmara pierwsze swoje dobra (Gródek Sołomerecki) zyskał od M.A. Sapiehy, a później również Siemków, który stał się jego siedzibą ${ }^{6}$, zaś sprawowana przy nim funkcja sekretarza pieczęci mniejszej litewskiej sprawiła, że stał się znany w całej Litwie ${ }^{7}$ Świeykowski zyskał swoje Kołodno, a także pierwsze dobra od Lubomirskich, co było - jak możemy przypuszczać - nagrodą za jego pomoc w interesach S. Lubomirskiego, wojewody bracławskiego ${ }^{8}$. Jeleńscy z kolei cieszyli się z dzierżaw wypuszczanych na korzystnych warunkach przez Radziwiłłów9 ${ }^{9}$ Wydaje się, że te „donacje” możemy we wszystkich

${ }^{4}$ O Chmarach dzierżących tylko małe Chmarzyszki można przeczytać w: Polska encyklopedia szlachecka, t. IV (Wykaz polskich rodzin szlacheckich), t. I, oprac. S.J. Starykoń-Kasprzycki, Warszawa 1936, s. 345-346; J. Ciechanowicz, Rody rycerskie Wielkiego Księstwa Litewskiego, t. II (A-D), Rzeszów 2001, s. 187; D. Rolnik, Adam Chmara (1720-1805) - ostatni wojewoda miński w świecie polityki czasów stanistawowskich i jego archiwum [w druku]. O Świeykowskich pisze D. Rolnik, Leonarda Marcina Świeykowskiego (1721-1793) ostatniego wojewody podolskiego życie codzienne i publiczne oraz jego myśli o Rzeczypospolitej, Katowice 2016, s. 39-40. O Jeleńskich także D. Rolnik, Województwo mińskie i Jeleńscy, s. 13-84.

${ }_{5}$ Por. D. Rolnik, Województwo mińskie i Jeleńscy, s. 99-128.

${ }^{6}$ O Gródku Sołomereckim pisze A. Boniecki, Herbarz polski, cz. 1 (Wiadomości historyczno-genealogiczne o rodach szlacheckich), t. II, Warszawa 1900, s. 392; Opisy parafii diecezji wileńskiej z 1784 roku, t. II (Dekanat miński), oprac. J. i M. Maroszek, Białystok 2009, s. 68-69. O planie nabycia tych dóbr por. Antoni Chmara ojciec do Adama Chmary, [Chmarzyszki?], 4 II 1745, BN, rkps 9001, k. 15v; i o transakcji: Antoni Chmara ojciec do Adama Chmary, Mińsk, 28 IV 1745, BN, rkps 9001, k. 19; Silva rerum A. Chmary, BJ, rkps 6211, k. 71. O przejęciu Siemkowa por. H. Mościcki, Chmara Adam, [w:] PSB, t. III, Kraków 1937, s. 315; R. Aftanazy, Dzieje rezydencji na dawnych kresach Rzeczypospolitej, t. I (Województwa mińskie, mścistawskie, potockie, witebskie), t. I, Wrocław 1991, s. 141; Opisy parafii diecezji wileńskiej, s. 82. Stan ten potwierdził podskarbi nadworny litewski Aleksander Michał Sapieha 27 VIII 1755 r. Por. Replika A. Chmary w sprawie dóbr siemkowskich, b.d. i m., NGAB, F. 1324, op. 1, rkps 23, k. 27-30v; Przen[iesienie] Prawa darowanego od JW. hrabi [M.A.] Sapiehy podkanclerz WKL panu Chmarze podczaszemu mińskiemu służące, [b.m.], 7 XII 1759, LVIA, Senieji Aktai, rkps 127, k. 404. Por. też Stownik geograficzny Królestwa Polskiego i innych krajów stowiańskich, wyd. F. Sulimierski, t. X, Warszawa 1889, s. 553.

${ }^{7}$ O przyjęciu funkcji w 1752 r. można przeczytać w: Silva rerum A. Chmary, BJ, rkps 6211, k. 78v, a o pierwszych sprawach, które załatwiał: Antoni Giełgud [starosta oszmiańki?] do A. Chmary, Grodno, 11 XI 1752, LNB, F. 103, dz. VIII, rkps 643, k. 21; Ignacy Pruszanowski do [A. Chmary], Kozłowiecze, 10 IX 1752, BJ, rkps 6637, k. 30; P. Pietraszkiewicz do A. Chmary, Nowogródek, 22 X 1752, BJ, rkps 6637, k. 48-49v; J.[ózef] Dulęba do A. Chmary, Warszawa, 4 XII 1752, BJ, rkps 6637, k. 81-81v.

${ }^{8}$ Por. D. Rolnik, Leonarda Marcina Świeykowskiego (1721-1793) ostatniego wojewody podolskiego życie codzienne i publiczne oraz jego myśli o Rzeczypospolitej, Katowice 2016, s. 106.

9 D. Rolnik, Województwo mińskie i Jeleńscy, s. 40-42, 67-71. 
wskazanych przypadkach traktować jako formę zapłaty bądź nagrody za ich służbę, ale zauważmy, że ta służba polegała na prowadzeniu przez „donatorów” małej dyplomacji w imieniu ich opiekunów; nieco mniejszą aktywność w tym czasie wykazywał Jeleński.

Wszyscy badani senatorowie w 1764 r. poparli na elekcji kandydata „familii”, wszak był to wynik orientacji politycznej ich opiekunów, choć trzeba także przyznać, że świadomie popierali program naprawy państwa tego stronnictwa ${ }^{10}$. Dopiero później, po pierwszym rozbiorze, ulokowali się silniej w stronnictwie królewskim, przy czym żaden z nich nie odgrywał i chyba nie chciał odgrywać w nim pierwszorzędnej roli na swoim obszarze działania. Na taki krok, jak wyraźny zwrot w stronę Stanisława Augusta decydowali się jednak w momencie, gdy na własnym terenie zyskali już stosunkowo silną pozycję, tak ekonomiczną, jak i polityczną, stając się potencjalnymi partnerami dla Stanisława Augusta. Jeleński w powiecie mozyrskim, Chmara w województwie mińskim i Świeykowski na Podolu, a ściślej na Bracławszczyźnie i w województwie podolskim. Byli już na tyle silni, by wyraziściej deklarować swoje sympatie i stawali się atrakcyjni dla króla, szczególnie Świeykowski ze względu na bliskie kontakty z Stanisławem Szczęsnym Potockim, dziedzicem nie tylko fortuny swego ojca Franciszka Salezego, ale jego politycznych wpływów, dzięki bogactwu poszerzanych już zresztą przez młodego Potockiego ${ }^{11}$. Przy czym w zasadniczych kwestiach wszyscy badani senatorowie z przekonania popierali szeroko rozumiany program Stanisława Augusta naprawy instytucji publicznych, a także prowadzenia polityki w oparciu o kontakty z Rosją, choć jej samej nie lubili i ewidentnie traktowali jako zło konieczne, zdając sobie sprawę z jej przewagi militarnej i politycznej, a zarazem mając świadomość potencjalnych zysków ekonomicznych wynikających z relacji handlowych, oczywiście pod warunkiem przestrzegania prawa. Nadużyciom Moskwy przy wybieraniu furażów przeciwstawiali się, na ile mogli, tzn. śląc poselstwa do Warszawy czy umieszczając odpowiednie punkty w instrukcjach poselskich $^{12}$. Silniejsze związanie się z obozem królewskim było kolejnym etapem na

${ }^{10} \mathrm{Na}$ elekcji nie było Świeykowskiego, ale byli jego bracia, zaś on sam miał mowę na sejmie konwokacyjnym wspierającą reformy „familii”. Por. L.M. Świeykowski do [?] Kierczyńskiego, Dubno, 29 VIII 1764, Biblioteka Raczyńskich w Poznaniu, rkps 3241, nl.; D. Rolnik, Leonarda Marcina Świeykowskiego (1721-1793), s. 364. Nie było też na elekcji G. Jeleńskiego, ale zjawił się Konstanty Ludwik Jeleński, jego bratanek - miała o to do niego pretensje „familia”. Por. D. Rolnik, Województwo mińskie i Jeleńscy, s. 153-156. Popierat „Familię” Chmara - por. Silva rerum A. Chmary, BJ, rkps 6211, k. 94v.

${ }_{11}$ D. Rolnik, Leonarda Marcina Świeykowskiego (1721-1793), s. 379-383.

12 Odpowiednio o Jeleńskim: Nota, [b.m. i d.] [1770?], NGAB, F. 1636, op. 1, rkps. 198, k. $164-$ 164v; D. Rolnik, Województwo mińskie i Jeleńscy, s. 173-174, 178. O Świeykowskim por. D. Rolnik, Leonarda Marcina Świeykowskiego (1721-1793), s. 395, 444-445; i o działaniach Chmary w tej kwestii: S. Łabowski do [A.] Chmary, Mohylew [?], 25 VIII 1765, NGAB, F. 1324, op. 1, rkps 62, k. 121v; A. Chmara do M. Chmarzyny, Grodno, 8 I 1766 [dwa listy], BN, rkps 9002/2, k. 95-95v, 97-98; Akt rekwizycji od księcia Dołgorukiego do województwa mińskiego, 13 II 1766, NGAB, F. 1727, op. 1, rkps 14, k. 660-661; Akt laudum sejmiku gromnicznego [II 1768], NGAB, F. 1727, op. 1, rkps 15, k. 24-25v. 
drodze budowy znaczenia ich rodzin w przestrzeni publicznej. $Z$ jednej strony ich ścisłe związki z wspierającymi ich rodzinami możnych Sapiehami czy Lubomirskimi uległy w sposób naturalny rozluźnieniu, a z drugiej strony zbliżenie do Stanisława Augusta pozwalało im jeszcze wzmocnić swoją pozycję w relacjach z rodzinami magnackim, od których dotąd w jakimś stopniu zależeli. Zaznaczmy tu wyraźnie, że nigdy jednak nie zamierzali przeciwko nim występować. Co więcej, starali się ciągle podtrzymywać z nimi współpracę ekonomiczną - szczególnie widoczne jest to w przypadku Świeykowskiego - który ekonomicznie współpracował z Potockim ${ }^{13}$ - i Chmary, który z kolei angażował się w przedsięwzięcia ekonomiczne z Aleksandrem Sapiehą i wdową po Michale Antonim Sapieże, Aleksandrą, która została po jego śmierci żoną hetmana litewskiego Ogińskiego ${ }^{14}$. Pod tym względem Jeleński, chyba mniej ambitny politycznie, zadowalał się pozycją w powiecie mozyrskim, choć i dla niego Sapieha kanclerz litewski był ważną postacią w interesach, tak publicznych, jak i ekonomicznych ${ }^{15}$. Natomiast wszyscy wzmiankowani politycznie bronili racji królewskich, ale w ten sposób, żeby nie narażać się Sapiehom i Radziwiłłom (w przypadku Jeleńskich i Chmarów) czy Potockim i Sanguszkom (w przypadku Świeykowskiego). Być może z tego wynikał ich dystans do angażowania się w życie sejmikowe. Owszem, cenili tę „źrenicę złotej wolności”, ale bardziej w teorii niż w praktyce.

Analiza postaw wspomnianej trójki senatorów pokazuje, że nie należeli z pewnością do grupy polityków sejmikowych. Wprawdzie pojawiali się na nich, ale zdecydowanie niechętnie, co widać w ich zachowaniu na sejmikach; gdy nie musieli, to się nie pojawiali $^{16}$. Nieco częściej na sejmikach bywał Jeleński, ale może wynikało to z faktu, że „jego” sejmik mozyrski był najspokojniejszy i obiektywnie najtańszy w obsłudze, ale również łatwiej mu na nim było działać, chociażby z racji jego przewagi ekonomicznej w powiecie i właściwie braku opozycji; jedynymi jego rywalami byli Oskierkowie, ale

${ }_{13}$ Te kontakty były stałe i nie ulegały politycznym koniunkturom. Por. D. Rolnik, Leonarda Marcina Świeykowskiego (1721-1793), s. 265, 285, 321, 323-324, 340, 384-385.

${ }^{14}$ O spławach, które często były przedsięwzięciami wspólnymi: F.[ranciszek] Zakrzewski do [A. Chmary], [b.m.], 27 II 1767, BJ, rkps 6646, k. 26-27; D.[ominik] Bukowski do A. Chmary, Raków, 5 i 12 I 1775, BJ, rkps 6652, k. 13-13v; M.F. Czartoryski do Hieronima Mejera wojskiego kowieńskiego, komisarza dóbr żmudzkich, Warszawa, 21 I 1773, LNB, F. 103, dz. VIII, rkps 643, k. 5; Franciszek Bielski do [A. Chmary?], Bohdaniszki, 15 IV 1775, NGAB, F. 1324, op. 1, rkps 27, k. 52v; Felix Szabański do A. Chmary, Dereczyn, 8 II 1790, BJ, rkps 6662, k. 39.

15 D. Rolnik, Województwo mińskie i Jeleńscy, s. 180-181.

16 W przypadku Chmary o jego nieobecności np.: J. Chmara do A. Chmary, Siemków, 13 II 1756, BJ, rkps 6640, k. 22; Instrukcja dla posłów mińskich, [Mińsk], 18 VIII 1778, NGAB, F. 1727, op. 1, rkps 17, k. 1424v-1427; M. Chmarzyna do męża A. Chmary, Raków [?], 17 II 1780, BStW rkps akc. 1780, k. 293; Akt dzieła obrad publicznych sejmików gromnicznych, [Mińsk], 11 II 1786, NGAB, F. 1727, op. 1, rkps 25, k. 80v. O Jeleńskim por. choćby: D. Rolnik, Województwo mińskie i Jeleńscy, s. 224-225. O Świeykowskim np. idem, Leonarda Marcina Świeykowskiego (1721-1793), s. 428, 431. 
z nimi jakoś zawsze się umiał porozumiećl ${ }^{17}$. Pod tym względem trudniejsza była sytuacja Świeykowskiego, który musiał rywalizować z Grocholskimi i Olizarami, za którymi stał Franciszek Ksawery Branicki ${ }^{18}$ i Chmary, który z kolei nie dysponował fortuną, jaka równoważyłaby wpływy Prószyńskich i Wołodkowiczów, za którymi czasami stał Antoni Tyzenhauz ${ }^{19}$. Ich nastawienie do życia sejmikowego nie zmieniło się też po uzyskaniu godności senatorskich. Jakkolwiek oni sami nieobecność na nich tłumaczyli wiekiem czy brakiem sił, to była raczej wynikiem świadomego wyboru. Wiele razy z tego powodu na swoich sejmikach się nie stawiali, a zaraz potem odbywali podróże do Wilna czy Warszawy. Natomiast gdy ich interes tego wymagał lub bardziej stanowczo żądał tego Stanisław August, jak przed sejmikami poselskimi 1788 r., wówczas pojawiali się na czele swoich sejmików, zazwyczaj z sukcesem ${ }^{20}$. Z pewnością jednak całą tę trójkę polityków możemy zaliczyć do grupy tych, którzy nie mieścili się w gronie zawadiaków sejmikowych, woleli raczej gabinety. Uczestniczyli w przygotowywaniu „plant sejmikowych”, przy wyborze deputatów, posłów czy urzędników elekcyjnych; wyraźnie dostrzec można ich większe zaangażowanie wówczas, gdy chodziło o wybór osób im bliskich ${ }^{21}$.

${ }^{17}$ D. Rolnik, Symbioza miasta, dworu i wsi jako podstawa funkcjonowania Jeleńskich w życiu publicznym Litwy czasów stanistawowskich - na przyktadzie powiatu mozyrskiego, [w:] Miestas. Dvaras. Kaimas. Lietuvos Didžiojoje Kunigaikštysteje ir Lenkijos Karalysteje XVI-XVIII a. Lokalines istorijos problemos, red. R. Šmigelskytė-Stukiené, Vilnius 2018, s. 157-176; S. Kościałkowski, Antoni Tyzenhauz. Podskarbi nadworny litewski, t. I, Londyn 1970, s. 198; D. Rolnik, Województwo mińskie i Jeleńscy, s. 182-183.

18 Por. D. Rolnik, Leonarda Marcina Świeykowskiego (1721-1793), s. 355-422.

19 Np. A. Chmara do [M.T. Łopacińskiego], Dereczyn, 28 IX 1757, LVIA, F. 1135, op. 14, rkps 18, k. 79; Excerpt procesów w datach. Rok 1785, NGAB, F. 1324, op. 1, rkps 24, k. 64-64v; A. Chmara do [M.T. Łopacińskiego], Dereczyn, 28 IX 1757, LVIA, F. 1135, op. 14, rkps 18, k. 79; Aktywacya excerptu dekretu konfederacyi generalney w sprawie J. Chmary z [?] Wołodkowiczem, 9 IX 1765, NGAB, F. 1727, op. 1, rkps 14, k. 483-486v; M. Chmarzyna do męża A. Chmary, Raków [?], 17 II 1780, BStW rkps akc. 1780, k. 293 - konflikt między tymi rodzinami z różnym nasileniem trwał do czasów sejmu 1788 r. Zatargi miał także z Prószyńskimi: Dekret oczywisty A. Chmary z Prószyńskimi, 5 IX 1781, NGAB, F. 1727, op. 1, rkps 45, k. 5v, 188-192v, ci często wspierali Wołodkowiczów.

${ }^{20}$ O sejmikach poselskich roku 1788 i aktywności Chmary: Regestr rzeczy wziętych na sejmiki od [?] Puzianowskiego, 21 VIII 1788, podpis A. Chmara, NGAB, F. 1324, op. 1, rkps 27, k. 262; Akt laudum prześwietnego województwa mińskiego, 21 VIII 1788, NGAB, F. 1727, op. 1, rkps 27, k. 399-399v; A. Chmara do Stanisława Augusta, [Mińsk], 21 VIII 1788, BCz, rkps 732, s. 165. O Świeykowskim na sejmikach roku 1788 por. D. Rolnik, Leonarda Marcina Świeykowskiego (1721-1793), s. 466-468. O G. Jeleńskim, osobiście nieobecnym, ale kontrolującym sejmik mozyrski, na który „przyjaciół dał”: D. Rolnik, Województwo mińskie i Jeleńscy, s. 224-225. Por. także J. Michalski, Sejmiki poselskie 1788 roku, [w:] idem, Studia historyczne z XVIII i XIX stulecia, t. I, Warszawa 2007, s. 240-243, 269-270.

${ }^{21}$ Por. np. w przypadku A. Chmary: Sejmik Akt laudum sejmiku gromnicznego 1785, [Mińsk], 10 II 1785, NGAB, F. 1727, op. 1, rkps 24, k. 81. Chmara został wówczas marszałkiem trybunału. W rok 1788 G. Jeleński pilnował, by posłem został jego bratanek K.L. Jeleński. Por. D. Rolnik, Województwo mińskie i Jeleńscy, s. 224-225. Aktywność Świeykowskiego wyraźnie większa była w roku 1782, gdy został marszał- 
Dokładnie nie wiemy, z czego brało się takie zachowanie i dystans do życia sejmikowego. Z pewnością jednak nie był to wynik ich tchórzostwa politycznego. Wydaje się raczej, że bliżsi byli załatwiania spraw na drodze „dyplomatycznej”. Każdy z omawianych senatorów miał wszakże w swoim życiorysie epizod sprzeciwiania się woli Stanisława Augusta. Chmara w 1776 r., kiedy w wyniku rozdwojonego sejmiku musiał uznać wybór na posłów swych adwersarzy i w 1787 r., kiedy pod naciskiem Stanisława Augusta musiał uznać elekcję na starostwo Michała Brzostowskiegoo ${ }^{22}$. Świeykowski poróżnił się z królem w połowie lat siedemdziesiątych ${ }^{23}$, zaś Jeleński miał pretensje do króla, że ten nie zauważał i nie nagradzał jego bratanków ${ }^{24}$. Wszystkie te spory były jednak szybko i skutecznie łagodzone, opisywani senatorowie łatwo szli bowiem na kompromis, rezygnując czasem z własnych ambicji, ale - co istotne - nie ze swych poglądów w zasadniczych kwestiach, co uwidoczniło się najwyraźniej w czasie Sejmu Wielkiego i konfederacji targowickiej, choć tylko Świeykowski opowiedział się wówczas wyraźnie po stronie związku Stanisława Szczęsnego Potockiego ${ }^{25}$. Chmara i Jeleński zachowali się powściągliwie. Pierwszy wprawdzie deklarował przychylność wobec ustawy majowej, ale z tego niewiele mogło wyniknąć, z czego zdawał sobie prawdopodobnie sprawę Stanisław August i wojewoda miński ${ }^{26}$. Drugi zaś zachował milczenie, by później wzywać swoich krewniaków do składania przysięgi wierności Katarzynie II, sam jednak swą postawę wytłumaczył Stanisławowi Augustowi ${ }^{27}$, natomiast z oficjalną przysięgą składaną na wierność Katarzynie II w imieniu guberni mińskiej pojechał Chmara ${ }^{28}$.

kiem trybunału koronnego oraz gdy pilnował wyboru na posła swego syna Jana Nepomucena w $1790 \mathrm{r}$. Por. D. Rolnik, Leonarda Marcina Świeykowskiego (1721-1793), s. 399-402, s. 505-509.

${ }^{22}$ Por. m.in. o podwójnej elekcji posłów w roku 1776: Silva rerum A. Chmary, BJ, rkps 6211, k. 100; A. Chmara do M. Chmarzyny, Warszawa, 16 IX 1776, BN, rkps 9002/2, k. 166-168v. Por. też A. Chmara do żony M. Chmarzyny, Warszawa, 28 VIII, 1, 9 i 13 IX 1776, BN, rkps 9002/3, k. 130-130v, 133-133v, 134-134v, 136. O elekcji starosty mińskiego wbrew planom Chmary: A. Chmara do Stanisława Augusta, Mińsk, 5 I 1787 i 9 II 1787, BCz, rkps 699, s. 231, 237-239; Kopia listu A. Chmary do O. Stackelberga, [b.m.], 10 II 1787, NGAB, F. 1324, op. 1, rkps 62, k. 42.

23 D. Rolnik, Leonarda Marcina Świeykowskiego (1721-1793), s. 373, 383, 392-393.

${ }^{24}$ Idem, Województwo mińskie i Jeleńscy, s. 230-232, 235-236.

25 Idem, Leonarda Marcina Świeykowskiego (1721-1793), s. 510-577.

${ }^{26}$ O postawie Chmary i Jeleńskiego: $Z$ dziejów związu targowickiego na Litwie. O powstaniu i dziatalności konfederacji mińskiej w latach 1792-1793, [w:] W podróży przez wiek osiemnasty. Studia i szkice z epoki nowożytnej, red. A. Perłakowski, M. Wyszomirska, M. Zwierzykowski, Kraków 2015, s. 317-336; D. Rolnik, Województwo mińskie i Jeleńscy, s. 244-245. Obaj są na liście czyniących recesa od przeszłego sejmu i akces do konfederacji targowickiej, choć Chmara zwlekał ze złożeniem takich oświadczeń. Por. Kancelarya WXL w uskutecznieniu zalecenia nayjaśnieszej konfederacji generalney [...] ma honor składać listę recesuiących od przeszłego seymu..., Lietuvos Mokslų Akademijos Vrublevskių Biblioteka w Wilnie, F. 17, rkps 28, k. 1, 44-47v.

27 D. Rolnik, Województwo mińskie i Jeleńscy, s. 261-263.

28 Por. relację z tej podróży spisaną przez sekretarza Chmary Jana Komara, Dyaryusz Podróży Petersburskiej. 1793 rok, oprac. A. Knychalska, Diariusz podróży do Petersburga, [w:] Z dziejów kultury czasów 
Świeykowski tego momentu nie dożył, zauważmy jednak, że uzasadniał swą postawę przed królem, a postawę samego króla w maju 1791 r. usprawiedliwiał złymi wpływami otoczenia ${ }^{29}$.

Również w swych województwach opisywani politycy starali się nie generować konfliktów, choć każdy z nich miał swego wroga. Chmara starostę hajneńskiego Józefa Wołodkowicza, Świeykowski Grocholskich, Jeleński zaś Oskierków, o czym już wspominano. Cała trójka potrafiła te konflikty odsuwać na bok w taki sposób, że nie tylko nie osłabiały ich pozycji w regionie - województwie - powiecie, ale nawet wzmacniały ją, ukazując ich jako umiejących walczyć o „swoje”, czyli zdolnych do walki także o powiat czy województwo, co też się ziszczało. Zyskiwali dzięki temu na autorytecie w swych środowiskach i z czasem zaczęli uchodzić - w czym pomagał im wiek - za mądrych polityków. Ponadto mieli umiejętność wskazywania ważnych do realizacji celów i - przynajmniej w skali mikro - robili to na oczach współbraci, a to przecież też cecha dobrego dyplomaty. Zawsze w odpowiednim momencie dostrzegali, która ze stron rywalizujących - na każdym szczeblu polityki krajowej - okaże się zwycięska, i po niej ostatecznie się znajdowali; tylko raz Chmara wybrał źle (przy wspomnianej już elekcji starosty mińskiego).

Warto wskazać na jeszcze jeden efekt ich małej „dyplomacji” i myślenia „dyplomatycznego": to kwestia budowania przez nich pozycji, czy szerzej, autorytetu na terenie ich aktywności politycznej. Osiągali to przez swoje odpowiednie zachowania i postawy, które doceniała miejscowa szlachta. Z jednej strony było to m.in. sprzeciwianie się woli Stanisława Augusta, z drugiej umiejętność utrzymywania dobrych relacji z największymi kresowymi rodami magnackimi, a ponadto, co jest wyraźne w ich działalności, okazywana dbałość o interesy województwa czy powiatu, co wiązało się również z kontaktami z dowódcami wojsk moskiewskich, które dawały się we znaki obywatelom kresów wschodnich Rzeczypospolitej w czasie całego panowania Stanisława Augusta, z wyjątkiem czasów Sejmu Czteroletniego. Wydaje się, że o ich talentach „dyplomatycznych”, ale również skutecznej na wielu płaszczyznach działalności świadczy fakt, że nie znaleziono w źródłach nawet jednej wzmianki, która by zarzucała im niskie pochodzenie. O ile w przypadku Jeleńskiego -wywodzącego się ze szlachty starej w powiecie mozyrskim i województwie mińskim - to nie musi zaskakiwać, o tyle w przypadku Świeykowskiego (człowieka nowego i bez majątku na kresach południowo-wschodniej Rzeczypospolitej) oraz Chmary (pochodzącego wprawdzie ze starej szlachty, ale

nowożytnych. Wybór tekstów źródtowych, red. M.E. Kowalczyk, Toruń 2009, s. 59-110. Por. D. Rolnik, Tropem politycznym i ideologicznym podróży petersburskiej Adama Chmary ostatniego wojewody mińskiego (1793), [w:] VIII amžiaus studijos. 6. Lietuvos Didžioji Kunigaikštysté. Personalijos. Idejos. Refleksijos, red. R. Šmigelskytè-Stukienè, Vilnius 2020, s. 106-115.

${ }_{29}$ Podobnie „zbałamuceniem” usprawiedliwiał postawę innych, którzy poparli reformy - m.in. prawa o miastach, przy tym za zbałamucenie czynił też odpowiedzialnym Stanisława Augusta, króla zaś bałamucili inni. Por. D. Rolnik, Leonarda Marcina Świeykowskiego (1721-1793), s. 534, 551, 582. 
z ubogiej, nic prawie nie znaczącej rodziny w województwie mińskim) może zastanawiać i być asumptem do rozważań nad kwestiami budowy karier w czasach stanisławowskich. Talenty, również „dyplomatyczne”, były przez współczesnych zauważane i doceniane. To poniekąd argument za tym, że oświecenie dotarło jednak do Rzeczypospolitej i drogi karier, w dużej mierze poszerzane przez Stanisława Augusta, opierały się już nie tylko na koneksjach, ale również na zdolnościach i fachowości, co sugerują biografie analizowanych postaci.

W większości ich działań możemy stwierdzić, że na poziomie polityki krajowej, województwa czy prowincji byli politykami skutecznymi i osiągali większość tego, co zamierzali. Zyskiwali to dzięki pewnemu wycofaniu i umiejętności prowadzenia dialogu. Swoje poglądy wyrażali ostrożnie, spraw nigdy nie stawiali na ostrzu noża. Także ich stabilna pozycja w rodzinie dodawała im autorytetu (pod względem moralno-etycznym były to rodziny bez zarzutu). Trudno powiedzieć, czy wszystko to wynikało ze znajomości zasad sztuki dyplomacji, ale na pewno możemy mówić o ich przyzwoitej kulturze politycznej, wynikającej ze zdrowego rozsądku, właściwej oceny aktualnej sytuacji. W przypadku zaś Chmary mamy do czynienia z wrodzonym talentem dyplomaty, co zauważali wszyscy współcześni mówiący: „grzeczny jak Chmara” ${ }^{30}$. Nieco inaczej szacunek i powagę, też w dyplomacji przecież ważne, zyskiwali Świeykowski - ten przez swą zasadniczość i wytrwałość w dążeniu do celu - i Jeleński - ten przez stanie na czele bardzo rozrodzonej rodziny, którą kierował jak władca udzielny, przynajmniej do czasu buntu jego bratanka Konstantego Ludwika. Cała trójka senatorów zyskała miano tych, z którymi musiano się liczyć w dużej mierze dzięki umiejętności dyplomatycznego poruszania się po meandrach krajowej polityki.

Oczywiście nie znamy dialogów z prowadzonych przez opisywanych polityków rozmów, ale na podstawie skutków ich działań możemy przyjąć, że umieli przekonywać do swoich racji i osiągać swoje cele. Pojawiali się tam, gdzie widzieli szanse na sukces i go osiągali, natomiast tam, gdzie nie byli pewni zwycięstwa się nie stawiali i racjonalnie usprawiedliwiali nieobecność. Mieli swoje poglądy i łatwo od nich nie odstępowali, jednak zdrowy rozsądek połączony z interesem własnym albo ogółu uzasadniał podejmowane przez nich decyzje. Wszystko to mieściło się w ramach dyplomatycznego postępowania. Pytanie tylko, na ile owa „dyplomacja” miała na celu ich własny interes, a na ile dobro Rzeczypospolitej. Dyplomatami byli dobrymi, czy jednak również tego pojęcia nie powinien definiować cel w postaci dobra publicznego? Jeżeli tak, to ocena ich talentów musi wypaść słabiej, przede wszystkim dlatego, że nie poświęcali ich dla służby państwu polsko-litewskiemu, ale wykorzystywali dla dobra swoich karier i małych ojczyzn. To nie tyle zarzut, ile konstatacja, którą trzeba brać po uwagę, analizując postawy polityczne osób zaliczających się do elit Rzeczypospolitej ostatnich dekad jej istnienia.

\footnotetext{
${ }^{30}$ H. Mościcki, Chmara Adam, s. 315.
} 


\begin{abstract}
No doubt the art of "diplomacy" as a skill or talent was beneficial to those who pursued a career path in the period of King Stanisław's reign. This property or capability made it easier for those who enjoyed it to make a career and it also made it easier for them to keep afloat in the public life. Such skills enabled a given person to stand out. However, the examples which are presented demonstrate the possibilities of the advancement of poor noblemen. In the period of King Stanisław's reign advancement was determined by aptitude and talent. Even though connections and background were important factors, their significance diminished gradually but discernibly. However, this change did not entirely entail a change of the thinking about the state. The new criteria of the making of elites were not always associated with ideological questions. In many cases a senator who was created, now not owing to his connections or background but owing to his talent, aptitude and the eponymous "diplomatic talent", thought in particularistic terms. Unfortunately, he did not always take into account the interests of the entire Rzeczpospolita. However, let us admit that he strove to combine his interests with the demands of the land in which he operated.
\end{abstract}

\title{
Keywords
}

Adam Chmara, Gedeon Jeleński, Leonard Marcin Świeykowski, Stanisław August, political life in the times of Stanisław August, political careers during epoch of Stanisław August. 